\title{
Hematological study of iron deficiency anemia and $\beta$ thalassemia trait in Sindhi community of Bundelkhand region of Madhya Pradesh with predictive value of red cell indices to discriminate them
}

\author{
Gangwani A. ${ }^{1}$, Shah M. ${ }^{2 *}$
}

DOI: https://doi.org/10.17511/jopm.2019.i07.06

\footnotetext{
${ }^{1}$ Amar Gangwani, Associate Professor, Department of Pathology, Bundelkhand Medical College, Sagar, Madhya Pradesh, India.

2* Mitesh Shah, Assistant Professor, Department of Pathology, Bundelkhand Medical College, Sagar, Madhya Pradesh, India.
}

\begin{abstract}
Background: Ethnic groups like Sindhis, Kutchis, Lohanas, Punjabis, few Muslim groups as well as few tribal populations have higher prevalence of hemoglobinopathy esespecially $\beta$ thalassemia carriers. $\beta$ Thalassemia traits are commonly misdiagnosed as iron deficiency anemia. Red cell indices are helpful to discriminate anemia and to detect subjects who have high probability of requiring appropriate follow up and to reduce unnecessary investigation cost. Aims and objectives: 1) To study red blood cell indices in all cases of microcytic hypochromic anemia. 2) Estimation of HbA2 levels and serum ferritin levels to confirmiron deficiency anemia and $\beta$ thalassemia trait. 3) To evaluate the diagnostic values of various red cell indices in discriminating iron deficiency anemia and $\beta$ thalassemia trait. Materials and methods: It is a prospective observation study carried out on Sindhi individuals of Sagar District of Bundelkhand region of Madhya Pradesh. Hemoglobin, RBC count, MCV, MCH and RDW were determined. Serum ferritin levels and HbA2 levels were detected. Result: Out of total 200 cases of Sindhi individuals 25 patients $(12.5 \%)$ were grouped in $\beta$ thalassemia trait while 175 patients (87.5\%) were grouped in iron deficiency anemia group on the basis of $\mathrm{HbA} 2$ and serum ferritin level. Significant difference was found inmean MCV, MCH, RDW and RBC count and showed high sensitivity and specificity to discriminate iron deficiency anemia from $\beta$ thalassemia. Conclusion: Sindhi community of Sagar district of Madhya Pradesh showed high prevalence of $\beta$ thalassemia trait. Mass awareness and proper pre marriage genetic counseling and prenatal diagnosis should be done to reduce the burden of disease.
\end{abstract}

Keywords: Sindhi, Iron deficiency anemia, $\beta$ Thalassemia trait, Red cell indices

Corresponding Author

Mitesh Shah, Assistant Professor, Department of Pathology, Bundelkhand Medical College, Sagar, Madhya Pradesh, India.

Email: drmiteshshah@gmail.com
How to Cite this Article

Gangwani A, Shah M. Hematological study of iron deficiency anemia and $\beta$ thalassemia trait in Sindhi community of Bundelkhand region of Madhya Pradesh with predictive value of red cell indices to discriminate them. Trop J Pathol Microbiol. 2019;5(7):449-453.

Available From

https://pathology.medresearch.in/index.php/jopm/ar ticle/view/287$$
\text { ticle/view/287 }
$$

\section{To Browse}

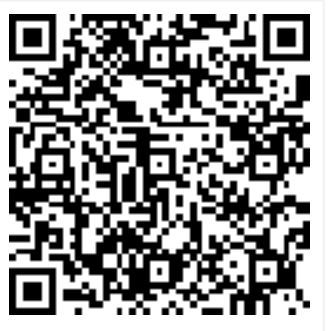




\section{Introduction}

Iron deficiency anemia and $\beta$ thalassemia traits are most common causes of microcytic hypochromic anemias in India and poses a major health problem $[1,2]$. The total expenditure on the management of hemoglobinopathies throughout the country is enormously high [3].

Carriers of haemoglobin disorders in the world are estimated to be 269 million. About 3\% of word population carry $\beta$ thalassemia gene. It is estimated that $50 \%$ of world $s$ population with $\beta$ thalassemia trait are in South east Asia [3]. Study of Kandhro et al determined ethnic-wise distribution of thalassemia trait in Sindh region of Pakistan, higher numbers of a- and $\beta$-thalassemia trait cases were seen in the Sindhi ethnic group [375 (64.21\%) and $283(69.02 \%)$, respectively] than in the other ethnic groups. In addition, a higher

Distribution of $\beta$-thal trait cases was observed in the Sindhi ethnic group $[n=327(56 \%)]$ in $a-$ and $\beta$ thalassemia cases overall [4]. Screening of anemias in sindhi community is essential as disease burden is high in this community. Mass awareness and proper counseling of positive cases plays a important role in prevention of inheritance of hemoglobinopathies [5].

A definitive diagnosis between $\beta$ thalassemia trait and iron deficiency anemia is based on $\mathrm{HbA} 2$ and serum ferritin levels [6]. But $\mathrm{HbA} 2$ and serum ferritin levels are costly investigations and are not available in small set up. So there should be methods which will screen and differentiate individuals for $\beta$ thalassemia trait and iron deficiency anemia at lower cost. Red blood indices are routine investigation done for almost every disease and even at set up.

So red cell indices like $\mathrm{RBC}$ count, $\mathrm{MCV}, \mathrm{MCH}$ and RDW can be helpful for differential diagnosis of iron deficiency anemia and $\beta$ thalassemia and reduce unnecessary cost [7-9]. Long term objective of this study was screening of anemic individuals of Sindhi community for thalassemia trait and to reduce the disease burden and preventing the inheritance by proper counseling and awareness also at lower cost and even in small set ups.

\section{Aims and Objectives}

- To study red cell indices in microcytic hypochromic anemia.
- Study of HbA2 levels using HPLC and serum ferritin levels using mini Vidas of all cases for confirmation of Iron deficiency anemia and $\beta$ thalassemia trait

- To evaluate the diagnostic values of red cell indices in diagnosis of iron deficiency anemia and $B$ thalassemia trait

\section{Material and Method}

Setting: Community based urban.

Duration of study: December 2018 to January 2019 (2 months)

Type of study: Cross-sectional study was carried out in Sindhi individuals of Sagar district, Bundelkhand region of Madhya Pradesh by organizing camps by Department of Pathology, Bundelkhand Medical College, Sagar.

Sampling method: Purposive sampling

Sample size calculation: 200 samples

\section{Inclusion Criteria}

- Individual having hemoglobin levels $<10 \mathrm{gm} / \mathrm{dl}$ for females and $<12 \mathrm{gm} / \mathrm{dl}$ for males

- Age group 5-35 years

- $\mathrm{MCV}<80 \mathrm{fl}$ and $\mathrm{MCH}<25$ pg for both genders

\section{Exclusion criteria}

- Individuals other than Sindhi community person residing outside Sagar district of Bundelkhand region of Madhya Pradesh.

- Diagnosed cases of any hemoglobinopathies.

Data collection procedure: Total 200 patients with were included in the study. $3 \mathrm{ml}$ of blood sample was collected in $\mathrm{K} 3$ - EDTA vials and $2 \mathrm{ml}$ of blood was collected in plain vials. EDTA samples were processed on Mindray BC 500 fully automated cell counter to measure Hemoglobin, RBC count, $\mathrm{MCV}, \mathrm{MCH}$ and RDW.

Serum ferritin levels were measured on plain vial samples by Mini Vidas fully automated immunoassay analyzer. HbA2 levels were measured on Bio rad D10 High performance Liquid Chromatography (HPLC) analyzer.

Diagnosis of iron deficiency anemia and $\beta$ thalessemia trait was made based on serum ferritin levels $<15 \mathrm{ng} / \mathrm{ml}$ and $\mathrm{HbA} 2$ levels $>3.6 \%$ respectively. 
Data analysis: Percentages were calculated for qualitative data. Means and standard deviation were calculated for quantitative data.

Unpaired t-test was used to compare means after looking at the distribution of variables for normality of data. P-value $<0.05$ was considered significant throughout.

Ethical consideration \& permission: An oral informed consent was taken from parents of children $<18$ years and individuals before including in the study. Study was approved by Institutional ethical committee of Medical College, Sagar (M.P.)

\section{Result}

A total of 200 patients with microcytic hypochromic anemia were included in the study comprising of 80 males and 120 females of which 175 cases were of iron deficiency anemia (105 females and 70 males) and 25 cases were of $\beta$ thalassemia trait (15 females and 10 males). In the present study age of patient varies from 5 to 35 years with maximum number of patients in age group of $15-30$ years. Of 80 males,35\% belongs to 5-14 years of age, $65 \%$ belongs to $15-35$ years of age. Of 120 females, $40 \%$ belongs to $5-14$ years and $60 \%$ belongs to $15-35$ years of age.

Table-1: Distribution of HbA2 levels in $\beta$ Thalassemia trait and Iron deficiency anemia patients.

\begin{tabular}{|l|l|l|l|}
\hline HbA2\% & $\begin{array}{l}\boldsymbol{\beta} \text { Thalessemia traitn- } \\
25\end{array}$ & $\begin{array}{l}\text { Iron deficiency anemia n- } \\
175\end{array}$ & P value \\
\hline $2-3.5$ & 0 & 172 & \\
\hline $3.6-5.0$ & 22 & 3 & \\
\hline $5.1-6.5$ & 3 & 0 & \\
\hline Mean $\pm \mathrm{S}$ & $3.8 \pm 0.63$ & $2.02 \pm 0.2$ & $<0.000$ \\
$\mathrm{D}$ & & $2-3.4$ & 1 \\
\hline Range & $4.5-6.2$ & & \\
\hline
\end{tabular}

Table-2: Distribution of serum ferritin level in $\beta T h a l a s s e m i a$ trait and Iron deficiency anemia patients.

\begin{tabular}{|l|l|l|l|}
\hline \multicolumn{1}{|c|}{$\begin{array}{c}\text { Serum } \\
\text { ferritin }\end{array}$} & $\begin{array}{l}\boldsymbol{\beta} \text { Thalassemia trait } \\
\mathbf{n - 2 5}\end{array}$ & $\begin{array}{l}\text { Iron deficiency anemia } \\
\mathbf{n 1 7 5}\end{array}$ & P value \\
\hline $\begin{array}{l}\text { Males } \\
\text { Mean } \pm \text { SD }\end{array}$ & $30.79 \pm 12.19$ & $15.16 \pm 3.85$ & \\
\hline Range & $20-62$ & $10.8-19.5$ & $<0.0001$ \\
\hline $\begin{array}{l}\text { Females } \\
\text { Mean } \pm S D\end{array}$ & $18.92 \pm 6.25$ & $8.78 \pm 2.95$ & \\
\hline Range & $11.0-25.0$ & $6.9-11.2$ & $<0.0001$ \\
\hline
\end{tabular}

Table-3: Comparison of RBC indices - $\beta$ TT and IDA

\begin{tabular}{|l|l|l|l|}
\hline \multicolumn{1}{|c|}{ RBC indices } & \multicolumn{1}{|c|}{$\begin{array}{c}\boldsymbol{\beta} \text { Thalessemia } \\
\text { trait } \mathbf{n - 2 5}\end{array}$} & \multicolumn{1}{|c|}{$\begin{array}{c}\text { Iron deficiency } \\
\text { anemia } \mathbf{n - 1 7 5}\end{array}$} & \multicolumn{1}{c|}{$\begin{array}{c}\mathbf{p} \\
\text { value }\end{array}$} \\
\hline MCV Mean \pm SD & $63.5 \pm 1.6$ & $65.2 \pm 4.1$ & $<0.01$ \\
\hline MCH Mean \pm SD & $19.2 \pm 0.6$ & $20.1 \pm 0.8$ & $\begin{array}{l}<0.00 \\
01\end{array}$ \\
\hline RDW Mean \pm SD & $15.8 \pm 0.91$ & $19.53 \pm 3.00$ & $\begin{array}{l}<0.00 \\
01\end{array}$ \\
\hline $\begin{array}{l}\text { RBC count males } \\
\text { Mean } \pm \text { SD }\end{array}$ & $5.81 \pm 0.91$ & $4.42 \pm 0.55$ & $<0.00$ \\
\hline $\begin{array}{l}\text { RBC count females } \\
\text { Mean } \pm \text { SD }\end{array}$ & $5.81 \pm 0.34$ & $3.23 \pm 0.57$ & $<0.00$ \\
\hline
\end{tabular}

On the basis of $\mathrm{HbA} 2$ levels $>3.6 \%, 25$ patients $(12.5 \%)$ of Sindhi community of Sagar district were grouped in $\beta$ thalassemia trait while 175 patients (87.5\%) having $\mathrm{HbA} 2$ level $<3.6 \%$ were grouped in iron deficiency anemia group.

The mean value for $\mathrm{HbA} 2$ in $\beta$ thalassemia group was $3.8+/-0.63$ and those in iron deficiency anemia group was 2.02+/-0.212 ( $p$ value $<0.0001$, significant).

The mean value of serum ferritin level was very much lower in iron deficiency anemia group as compared to those in $\beta$ thalassemia group.( $p$ value $<0.0001$ significant).

In the present study mean $\mathrm{MCV}$ and $\mathrm{MCH}$ in $\beta$ thalassemia cases were $(63.5 \pm 1.6)$ and (19.2 \pm 0.6$)$ respectively, which was lower than those found in iron deficiency anemia i.e.(65.2 \pm 5.3$)$ and $(20.1 \pm 0.8) \quad$ respectively. $(p \quad$ value $<0.0001$ significant)

The mean RDW values were increased in both the groups but the iron deficiency anemia group showed the higher values i.e. $19.53 \pm 3.00$ as compared to $\beta$ thalassemia group15.8 \pm 0.91 ( $p$ value $<0.0001$ significant)

The mean RBC count in $\beta$ thalassemia group were higher i.e. $5.81 \pm 0.34$ in males,4.92 \pm 0.55 in females as compared to iron deficiency group i.e. $4.29 \pm 0.49$ in males, $3.23 \pm 0.57$ in females ( $p$ value $<0.0001$ significant)

In 25 cases of $\beta$ thalassemia, 10 cases (40\%) were females and 15 cases (60\%) were males.

In 175 cases of iron deficiency anemia 105 cases $(60 \%)$ were females and 70 cases (40\%) were males. 


\section{Discussion}

Hemoglobinopathy is a hematological disorder occurring due to the modification in the genetically determined molecular structure of hemoglobin. India has an extreme diverse population of 1.30 billion. It comprises numerous castes, sub castes, and tribal groups in different geographic regions. Due to large scale migration of population of Sindhi community during partition of India in 1947, the prevalence of hemoglobinopathy in Sindhi community is quite variable.

In India, on an average estimate $8000-1000$ children are born every year with thalassemia major disease [10]. Several studies in the literature have reported that Sindhi community has high frequency of thalassemia along with similarity in clinical features of iron deficiency and traits of $\beta$ thalassemia $[7,11]$. In the present study, traits of $\beta$ thalasemia and iron deficiency anemia cases were confirmed by $\mathrm{HbA} 2$ levels and serum ferritin levels with the study of red cell indices $M C V, M C H, R B C$ count and RDW.

The evaluation of the reliability of different RBC indices in Pelestinian population was studied by Sirdan et al [12] and it was concluded that these indices had highest accuracy in differentiation between $\beta$ thalassemia trait and iron deficiency anemia. In the areas of high prevalence of $\beta$ thalassemia, the utilization of cell counter based parameters for the detection of $\beta$ thalassemia was studied by Rathod et al [9]. In the present study, the mean MCV (63.5 \pm 1.6$)$ and MCH $(19.2 \pm 0.6)$ in $\beta$ thalassemia cases were lower than those found in iron deficiency anemia cases i.e. (65.2 \pm 5.3$)$ and $(20.1 \pm 0.8)$ respectively with significant $p$ value of $<0.0001$.

The mean RDW values were increased in both the groups but the iron deficiency anemia group showed the higher values i.e. $(19.53 \pm 3.00)$ as compared to the $\beta$ thalassemia group $(15.8 \pm 0.91)$ with significant $p$ value of $<0.0001$. The mean RBC count in $\beta$ thalassemia group were higher i.e. $(5.81 \pm 0.34)$ in males in comparison to the iron deficiency group i.e. $(4.29 \pm 0.49)$ with significant $p$ value of $<0.0001$. The observations recorded in the present study were comparable to the outcomes obtained from the studies of Jaswani et al.[13], Soliman et al [14] and Bhushan et al [15]. Other Indian author found similar observation $[14,15]$.

A significant difference can be observed in the
Present study, study of Jaswani et al, and Soliman et al in terms of MCV, RDW and RBC count in iron deficiency and $\beta$ thalessemia cases. Study of Jassim [16] found MCV (62.36 \pm 9.63$), \mathrm{MCH}(19.25 \pm 2.37)$,

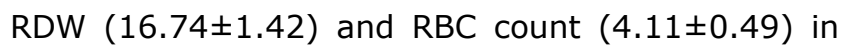
iron deficiency anemia cases while MCV

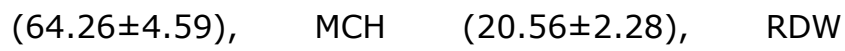
$(13.6 \pm 2.69)$ and $\mathrm{RBC}$ count $(5.6 \pm 0.72)$ in $\beta$ thalessemia cases with the RBC count, $\mathrm{MCH}$ were observed to be significantly lower in iron deficiency anemia cases than in the group of $\beta$ thalessemia trait while RDW was significantly found to be higher in the cases of iron deficiency anemia than in the cases of $\beta$ thalessemia trait, significant difference was not observed for MCV.

Thus red cell indices like MCV, MCH, RDW and RBC count can act as effective screening methodology when used in conjunction for iron deficiency and thalassemia patients.

\section{Conclusion}

Sindhi community has high prevalence of thalassemia. $\beta$ thalassemia and iron deficiency anemia are common causes of microcytic hypochromic anemia. The real danger of non diagnosis and misdiagnosis of $\beta$ thalassemia trait is potential homozygous offspring. Appropriate screening, detection of patients and proper genetic counseling of couples at risk are most important measures for the reduction of morbidity and mortality.

More efforts are needed to increase awareness in high risk communities like Sindhis. Red cell indices are helpful to discriminate and follow up of microcytic hypochromic anemia cases and to reduce unnecessary financial burden for diagnosis and treatment of $\beta$ thalassemia.

\section{What the study adds to the existing knowledge?}

Present study found $\mathrm{MCV}, \mathrm{MCH}$ and RDW were more low in $\beta$ thalassemia than iron deficiency anemia cases while RBC count is higher in $\beta$ thalassemia trait cases than in iron deficiency anemia.

\section{Author's contribution}

Study mainly conducted by Dr. Amar Gangwani while data interpretation and manuscript writing done by both Dr. Amar Gangwani and Dr. Mitesh Shah. 


\section{Reference}

01. Kafle S, Lakhey M. Etiological study of microcytic hypochromic anemia. J Pathol Nepal. 2016;24;6(12)994-7. DOI: 10.3126/jpn.v6i12.162 80 [Crossref][PubMed][Google Scholar]

02. Singh M, Gautam A. To evaluate anaemia by erythrocyte indices, red cell distribution width and haemoglobin electrophoresis with special reference to thalassemia in paediatric age group. J Evol Med Dent Sci. 2015;4(11)1755-64. [Crossref][PubMed] [Google Scholar]

03. Angastiniotis M, Modell B. Global epidemiology of hemoglobin disorders. Ann N Y Acad Sci. 1998;850;251-69. DOI: 10.1111/j.1749-6632.199 8.tb10482.x [Crossref][PubMed][Google Scholar]

04. Kandhro AH, Prachayasittikul V, Isarankura NaAyudhya C, Nuchnoi P. Prevalence of Thalassemia Traits and Iron Deficiency Anemia in Sindh, Pakistan. Hemoglobin. 2017;41(3)157-163. DOI: 10.1080/03630269.2017.1345759 [Crossref] [PubMed][Google Scholar]

05. Cao A, Kan YW. The prevention of thalassemia. Cold Spring Harb Perspect Med. 2013;3(2)a011775. DOI: 10.1101/cshperspect.a011775 [Crossref] [PubMed][Google Scholar]

06. Vehapoglu A, Ozgurhan G, Demir AD, UzunerS, Nursoy MA, Turkmen $S$ et al. Hematological indices for differential diagnosis of Beta thalassemia trait and iron deficiency anemia. Anemia. 2014. DOI: 10.1155/2014/576738 [Crossref][PubMed][Google Scholar]

07. Jameel $T$, Baig M, Ahmed I, Hussain MB, Alkhamaly MBD. Differentiation of beta thalassemia trait from iron deficiency anemia by hematological indices. Pak J Med Sci. 2017;33(3)665-669. DOI: 10.12669/pjms.333.12098 [Crossref][PubMed] [Google Scholar]

08. Urrechaga E, Borque L, Escanero JF. The role of automated measurement of RBC subpopulations in differential diagnosis of microcytic anemia and $\beta$ thalassemia screening. Am J Clin Pathol. 2011;135 (3)374-9. DOI: 10.1309/AJCPJRH1IOXTNFGA [Crossref][PubMed][Google Scholar]

09. Rathod DA, Kaur A, Patel V, Patel K, Kabrawala $R$, Patel $V$, et al. Usefulness of cell counter-based pa rameters and formulas in detection of beta-thala ssemia trait in areas of high prevalence. Am J Clin Pa thol. 2007;128(4)585-9. DOI: 10.1309/R1YL
4B4BT2WCQDGV[Crossref][PubMed][Google Scholar]

10. Colah RB. Strategies for prevention of thalassemia and hemoglobinopathies. J Assoc Physicians India. 1994;42(10)810-4. [Crossref] [PubMed][Google Scholar]

11. Rakholia $R$, Chaturvedi P. Prevalence of $\beta$ thalassemia carrier state in Sindhi community of Wardha and evaluation of risk factors for $\beta$ thalassemia trait. Niger J Clin Pract. 2013;16(3)375-80. DOI: 10.4103/11193077.113468 [Crossref][PubMed][Google Scholar]

12. Sirdah M, Tarazi I, Al Najjar E, Al Haddad R. Evaluation of the diagnostic reliability of different $\mathrm{RBC}$ indices and formulas in the differentiation of the beta-thalassaemia minor from iron deficiency in Palestinian population. Int J Lab Hematol. 2008;30(4)324-330. DOI: 10.1111/j.1751553X.2007.00966.x [Crossref][PubMed][Google Scholar]

13. Jaswani P, Nigam RK, Kothari S. Clinicohaematological study of iron deficiency anaemia and b-thalassemia traitpredictive value of Sehgal index and various complete blood count indices to discriminate between iron deficiency anaemia and b-thalassemia trait and confirmation using haemoglobin electrophoresis/ HPLC. J Evol Med Dent Sci. 2018;7(17)2118-25. [Crossref][PubMed] [Google Scholar]

14. Soliman AR, Kamal G, Walaa AE, Mohamed TS. Blood indices to differentiate between $\beta$-thalassemia trait and iron deficiency anemia in adult healthy Egyptian blood donors. Egypt J Haematol. 2014;39(3)91. DOI: 10.4103/1110-1067.148223 [Crossref][PubMed][Google Scholar]

15. Reema B, Shailaja S, Divyanshu S, Ss T, Sunita S. Reliability of Different RBC Indices to Differentiate Between Beta Thalassemia Trait and Iron Deficiency Anemia During Antenatal Screening. World J Pathol, 2018;7(3)14-20. [Crossref] [PubMed][Google Scholar]

16. Jassim AN. Comparative behavior of red blood cells indices in iron deficiency anemia and $\beta$ thalassemia trait. Iraqi J Hematol. $20161 ; 5(2) 183$. DOI: 10.4103/2072-8069.198129 [Crossref] [PubMed][Google Scholar] 